\title{
コーデクス規格に反映されたミネラルウォーター の性質と背景 \\ Codex Standards for Packaged Waters that Reflect Backgrounds and Properties of the Waters
}

\author{
福 田正 彦 \\ (社)全国清涼飲料工業会)
}

\section{はじめに}

ミネラルウォータといえば“容器に入った水”を指す のが我が国の一般的な理解であるし，外国でも内容をあ まり詮索せずにマスコミなどで気軽にこの用語が使われ ている，しかし，国際的な食品規格の中では，いま「ミ ネラルウォーター」といら用語を巡って大きく摇れてい る.なぜそうなのか。これは世界各地の水の性質や，そ の水がもたらした食文化などを背景とした経済競争が国 際規格の策定に大きな影響を与えているからである．食を 品について世界共通の規格を作ろらという動さがいわゆ るコーデクスといわれる国際食品規格だが，水に関する 性質や背景などが，コーデクス規格にどのように影響し ているかを見てみたい。

\section{1.コーデクスとは何か}

正式には「コーデクス・アリメンタリウス」といって, ラテン語からきた言葉である。意味は食品規格集といら ことで，多くの食品規格を一つに（実際には何冊かにな っているが) まとめたもの. しかし, 単独の国際規格で もコーデクスと呼ぶし，またこれに関連する規定や組織 にはすべてコーデクスと名前が付く.

国連の専門機関である国連食糧農業機関（F A O ）と 世界保健機関（WHO）が連合して食品国際規格計画を 作ることが決まっているが，その実施機関が Codex Alimentarius Commission で, 我が国では国際食品規格 委員会 $(\mathrm{CAC})$ といっている. C A C には多くの下部 機関 (部会) があってコーデクス規格を策定しているが, 大きく分けると一般問題を担当する部会と, 個々の食品

本稿は第18回研究集会の発題講演を緾めたものである.
規格部会，それに世界各地域の問題を担当する地域調整 部会がある。一般問題部会とは，例えば食品衛生部会や 食品表示部会であり，個々の規格部会には乳・乳製品部 会や糖類部会などがある.ナチュラルミネラルウォー ターもこの部会の一つで，ホスト国はスイスである，C $\mathrm{AC}$ の組織図を図 1 に示す.

コーデクス規格には三つの種類があり, 国際規格（スタンダード） 推薦国際規範（リコメンデーション） ガイドライン

となっている．この三つともコーデクスではあるが，通 常は国際規格をコーデクス規格と呼ぶことが多い.

C A C の目的の第一は「消費者の健康を保護し, 食品 貿易に括ける公正な慣行を保証する」ことである。コ一 デクスは直接の強制力は持たないが，WTO（世界貿易 機関）体制下では国際的な紛争を解決するための基準と なって括り, 現にS P S協定（衛生と植物検疫の規準適 用に関する協定）とT B T協定（貿易にお梳術的障 壁に関する協定）を批准している我が国では，何らかの 国内規格を作る場合には原則としてコーデクスを無視て きない、その意味からもコーデクス規格は大きな影響力 を持っている.

\section{2. 現在のミネラルウォーターのコーデクス}

容器に入った水のコーデクスといら意味では現在 2 種 類で四つある.

1.ナチュラルミネラルウォーター

(1)コーデクス・スタンダード : CODEX STAN. 1081981, Rev. 1-1997

(2)推薦国際衛生規範 : CAC/RCP 33-1985

2.ボトルド/パッケージドウォーター 


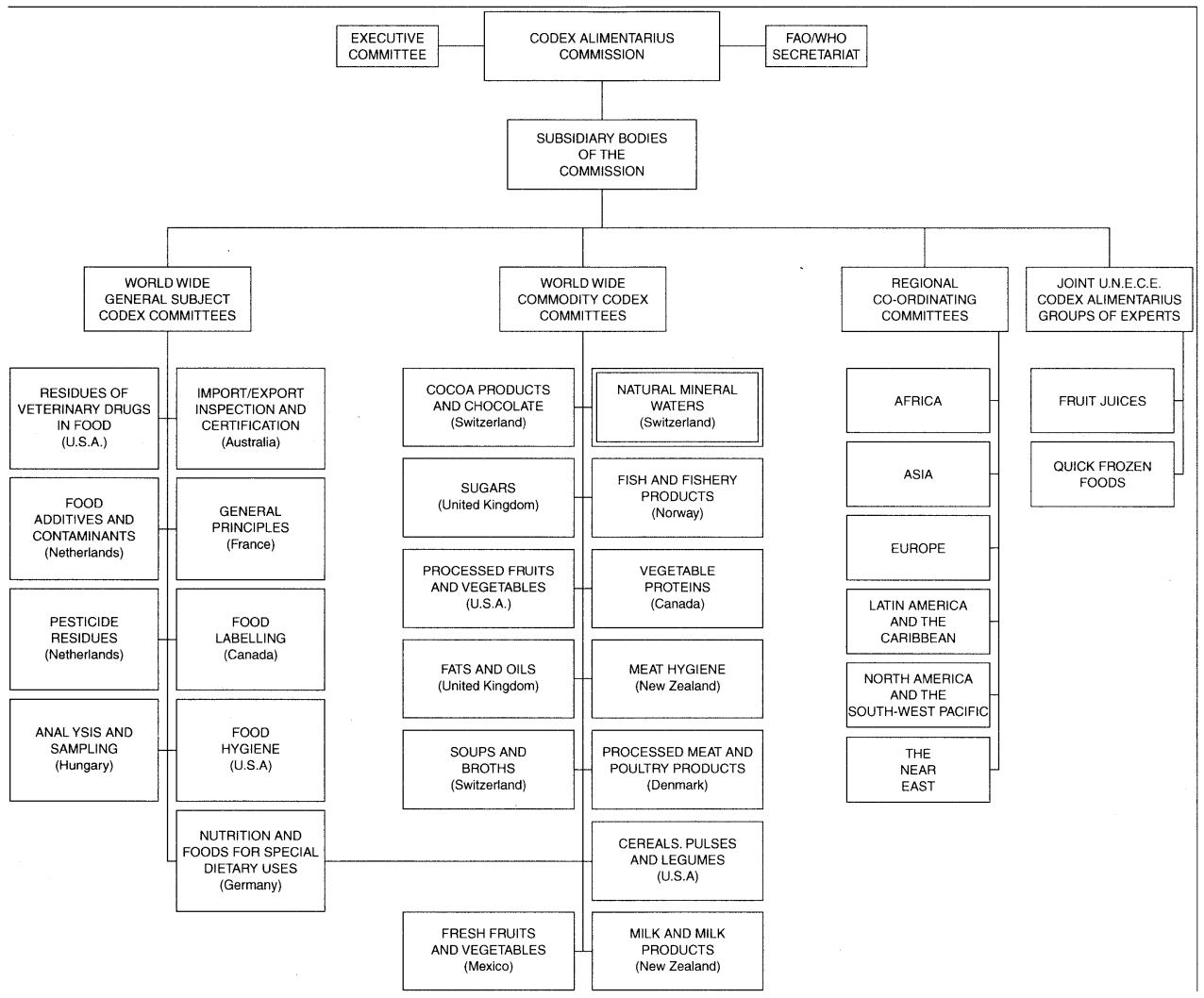

図 1 Codex Alimentarius Commission

(1)コーデクス・スタンダード：（現在策定中ステッ プ 3 )

(2)推薦国際衛生規範：（現在策定中ステップ 8)

この 2 種類のらちナチュラルミネラルウォーターはど ちらもすでに決まっている，スタンダードが1997年に改 訂されたのは，それまでヨーロッパ地域規格であったも のを世界規模規格に改訂したものである。ボトルドウ オーターの方は, スタンダードが現在ステップ 3 , 衛生 規範はステップ 8で, 次回の C A C 総会で承認されれば これが確定する.

\section{3.なぜ 2 種類あるのか}

水のコーデクス規格は本来, ボトルドウォーターある いはパッケージドウォーターといらすべての容器入り飲 用水を包含した広い規格として設定されるべきもので， ナチュラルミネラルウォーターはその中の一種として分 類されるのが本当だろら. しかし，ヨーロッパはナチュ ラルミネラルウォーターは“ヨーロッパの伝統的産物で
あり, 他の水とは違ら特別もの” と主張して, それ意外 のパッケージドウォーターと一緒にすることを断固拒否 した。したがって，ボトルド/パッケージドウォーター を指す場合，ヨーロッパはたとえ1行毎であっても必ず 「(ナチュラルミネラルウォーター以外)」といら括弧付 きの言葉を入れる汪ど神経質になっている.

そのために，コーデクスは規格も規範も同じ容器入り 飲用水であるのに 2 種類あることになった.

\section{4. 地域的な背景とコーデクス}

ナチュラルミネラルウォーターに関してはヨーロッパ の伝統はかなり古い，しかし，その起源はどちらかとい らと“飲屯温泉”から始まったといってよい。つまり， 飲用治療がその根底にある．昔，といっても1950年代の ことだが，フランスの法規ではナチュラルミネラルウ ォーターの定義の第一の要件に “治療効果のあること” が挙げられていたことからもこれは明らかである。

ドイッでも，1930年代の法規では総溶解固形分（T D 
S ）が $1000 \mathrm{mg} / \mathrm{l}$ 以上なければミネラルウォーターで はなかった。これも治療効果を念頭に置いたものであろ ら、ヨーロッパはもともと喉が渴いたから水を飲をとい ら習慣があまりない地域だから，ナチュラルミネラルウ ォーターは飲み水としてではなく, 有名な源泉の水を簡 単に入手する手段として容器に入れて販売されたものだ った. ヨーロッパ産ナチュラルミネラルウォーターの名 称は，多くが源泉の地名であるのはここから来ている.

現在のコーデクス規格では治療効果の表示を否定して いるが，こういった伝統的な考光方は十分に生き残って いて,ナチュラルミネラルウォーターのコーデクスでは,

(1) 源泉の好気性微生物叢（フローラ）を維持するこ と

(2) 源泉地のすぐ近くでビン詰めし，バルク輸送をし ないこと

(3) 殺菌, 除菌処理をしないこと が重要な中心的要件となっている.

一方，我が国では昔から豊富な水に恵まれているし， 水そのものを飲料や食材として使ってきた。喉の渴いた ときに生の水を飲むことはもちろん，打茶を入れる，ご 飯を炊く，豆腐を作るなど，調理の原料としても使う．

我が国で水に対する一般の反応を見ると，真っ先にで てくるのが「おいしい水」である、喉の渴きを癒す飲料 あるいは食材，という基本的な概念からすれば当然「物 いしさ」が評価の第一に挙がるであるう。また調理の対 象である食材だから，水を加熱することは日常茶飯事だ ったとい光る。

ごく最近まで，こういった環境があったから，ヨーロ ッパとは逆に，すぐ手近にあり何時でも良質の水が手に 入れられるばっかりに, 水を容器に入れて販売するとい ら発想そのものがなかったといっていい，もちろん，日 本でも温泉は古くから利用されてはいたが，どちらかと いらと入浴治療に重点があり, 飲用治療は現地で飲もこ とはあっても，それが大々的に治療場で行われることは なかった。まして飲用治療の対象として源泉をビン詰め にしょらといらこともなかったのである，我が国では水 を治療のためではなく, 飲料や食材として人々に受け入 れられてきたし，現在でもそらである。

アメリカの場合はボトルドウォーターが発展したのは 比較的最近で，急激に增えたのは1978年からである。ア メリカでのボトルドウォーターの役割はどちらかといら と“水道水の代わり”といら概念である.どらもアメリ 力人は水道水に不信感を持っているよらで，そのために 多くのボトルドウォーターは20リットル汪どもある大量
容器で事務所や家庭向けに販売されている.アメリカ人 のボトルドウォーターに対する期待を一言でい党ば “安 全性（Safety）”であろう。

ボトルドウォーターの規制を管轄しているのはF D A （食品医薬品局）で，その規制を見るとすべてのボトル ドウォーターに殺菌やバルク輸送をを許している. 細か い点は別として, 基本的にボトルドウォーターに対する 考え方は我が国と同じである.

こういった世界各地域の概念の相違があるために, ナ チュラルミネラルウォーターのコーデクスを決めるとき には大論争になった。 ヨーロッパとその周辺国が一方に あり，それ以外の国々がその対極にあるといら様相だっ た.簡単にい壳ば,ナチュラルミネラルウォーターはヨー ロッパ特産の伝統ある製品だから, 他の水と違ら特別な ものだといら一方の主張に対して, 地域規格であるなら ばともかく，世界規模規格にしょうといら時に，一地域 であるヨーロッパの規格をそのまま押しつけるのでは， 条件の違う地域には適用できないではないかといらこと である。

水に限らないが, こういった対決はコーデクス規格の 策定では上く問題になることで，アメリカに代表される 各国はコーデクス規格を科学的な裏付けに基づいて策定 すべきだと主張し，ヨーロッパはそれ以外に消費者の感 情といった要素も配慮すべきだと主張して対立する。

配慮すべき消費者の感情といらのはどういらことかは っきりしないが, 例えば,ナチュラルミネラルウォーター で原水のバルク輸送を禁止しているのは, 科学的にい光 ば何の意味もない、ヨーロッパは污染の“可能性が増兄 る”のを根拠としてそらいらのだが，衛生的に取り扱う 方法はいくらでもある. 衛生的に取り扱らことを条件に してバルク輸送を許しても一向に差し支えないのだが, それを禁止しているのはナチュラルミネラルウォーター に“他の水とは違う特別なもの”であるための証左とい ら役割を負わせているからに法かならない。

こういった議論は論理で解決できないし、コーデクス の会議で強調される“コンセンサス”を得ることもかな り難しい，最終的には数の論理がものをいらことになる のである.

こらしてナチュラルミネラルウォーターのコーデクス 規格の採択はＣＡＣの総会で最後に投票となり，33対 31 棄権10といらきわどいところで数に押し切られた. 我が 国もアメリカも，この決定に対して態度保留を宣言して いる. 
日本食生活学会誌

\section{5. 水の性質と食文化}

食文化というと大げさだが，その地域の水の性質が食 習慣にもたらした影響は無視し得ない。前項で述べたよ らな考方方の相違には，その地域の水の性質が大きく影 響を与えている。そのあたりを少し見てみよう。

先ず総溶解固形分（T D S ）だが，分析值を見ると平 均してヨーロッパが断然多く最大で $10,000 \mathrm{mg} / l$ を超光 るが，少ない方も $30 〜 40 \mathrm{mg} / l$ といらのがある. ヨーロ ッパは地域的に T D S の分布範用がきわめて広い，かな り下がってアメリカと中国が似たよらな傾向を示す。た だし，中国の方がアメリカよりも平均してやや多く， $100 \mathrm{mg} / l$ から $1,000 \mathrm{mg} / l$ ぐらいに分布する. 最も少ない のは日本と韓国で 50 から $200 \mathrm{mg} / l$ と見ていいだろう。詳 細を図 2 に示す.

特徵的なのは重炭酸イオンである.ヨーロッパでは $50 \mathrm{mg} / l \sim 4,000 \mathrm{mg} / l$ の間に分布するが，最高では 6,000 $\mathrm{mg} / l$ にもなる．次いで中国も多く，集中带は $150 \mathrm{mg} / l$ $\sim 350 \mathrm{mg} / l$ で, アメリカの $60 \mathrm{mg} / l \sim 250 \mathrm{mg} / l$ よりも少 し多い。日本と韓国は最も少なく，日本では $20 \mathrm{mg} / l \sim$ $65 \mathrm{mg} / l$, 韓国で $20 \mathrm{mg} / l \sim 110 \mathrm{mg} / l$ ほどになる。詳細を 図3 に示す。

もら一つ特徵があるのはシリカである. 他の成分と違 ってこ机りいては日本がかなり多い、ヨーロッパも北 アメリカも韓国も匡ぼ $40 \mathrm{mg} / l$ 以下（アメリカは少数の 例外があるが）で，平均的には $15 \mathrm{mg} / l \sim 20 \mathrm{mg} / l$ であろ らか。しかし，日本と中国は $200 \mathrm{mg} / l$ ほどまで分布し， 平均は $30 \mathrm{mg} / l \sim 40 \mathrm{mg} / l$ ⿷どである.やはり地質が大き く影響しているのだろう。詳細を図 4 に示す。

こういった水の性質から見ると，ヨーロッパの水を加 熱したならば,ほとんど炭酸塩となって沈殿するだろう.
また炭酸ガスの混入がかなり多いことも想像される．日 本人はT D S とい，重炭酸塩の量といい，かなりあっ さりした水に囲まれ，しかも水を加熱することを当たり 前と思って育ったといえる. 一方アメリカは処理水が大 部分だから，あまり水質には影響されないのである。

ヨーロッパの特質といっていい炭酸ガスについていえ ば，ヨーロッパの習慣がそのままコーデクスに反映され ている. 天然のガスを源泉地で分離し，（ガスを処理し た後で）再度溶け込ませても，源泉のガスで強化しても， 源泉のガスを少なくしても，更にいえば源泉以外から持 ってきたガスを注入しても，すべて“ナチュラルミネラ ルウォーター”である.いかにヨーロッパ人がガス入り のミネラルウォーターを常用しているかといら訨拠であ 万う。

これはむしろ日常の食物の質, 例えば脂肪の摂取量と か，味をかなり中和する米飯の摂取の多さとか，言って みれば洋食と和食といら食事の質の差が炭酸ガス入りの 水を要求するかどらかの基準となるようにも思える.

このように各国, 各地域の習慣や伝統がューデクスに 反映されているが，こういったものは単に規格を作った からといって一朝一夕に変えられるものではない，例え ば, 食品の分類表で, 我が国では先ず米, 麦などの穀類 が先頭であろらが，ヨーロッパの分類の先頭は乳・乳製 品である.

世界規模規格からすれば，一地域のみの伝統などで縛 られたものは問題がある。なぜかといえば，各地域の伝 統的な産業を阻害しかねないし，それこそ公正な貿易之 は矛盾するからである。もしろ地域特性の強いものは地 域規格に止め，世界規模規格については衛生面など世界 的に共通する部分のみの緩やかな規格とすべきではなか ろらか。 
日本食生活学会誌 Vol.11 No.1（2000）

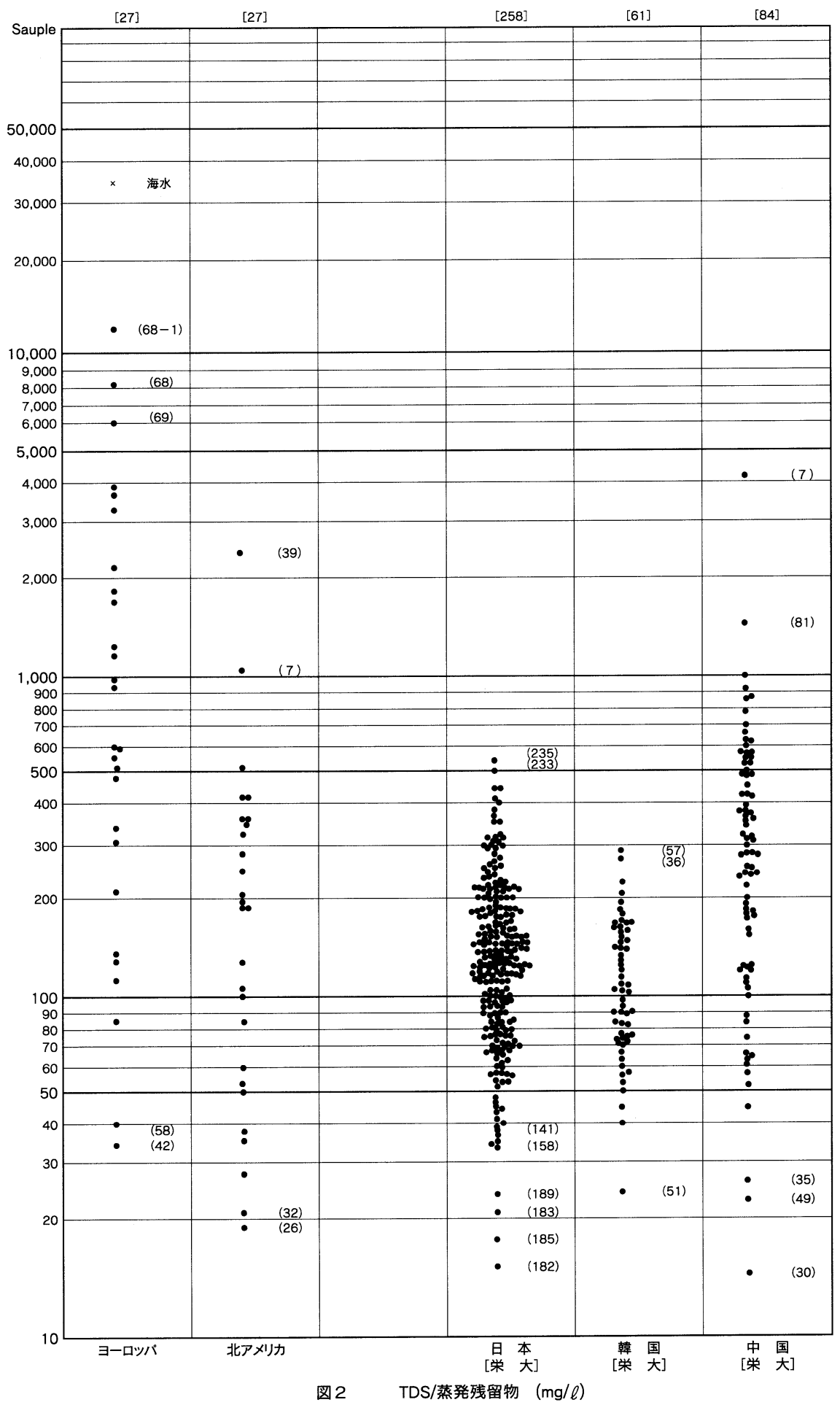


日本食生活学会誌

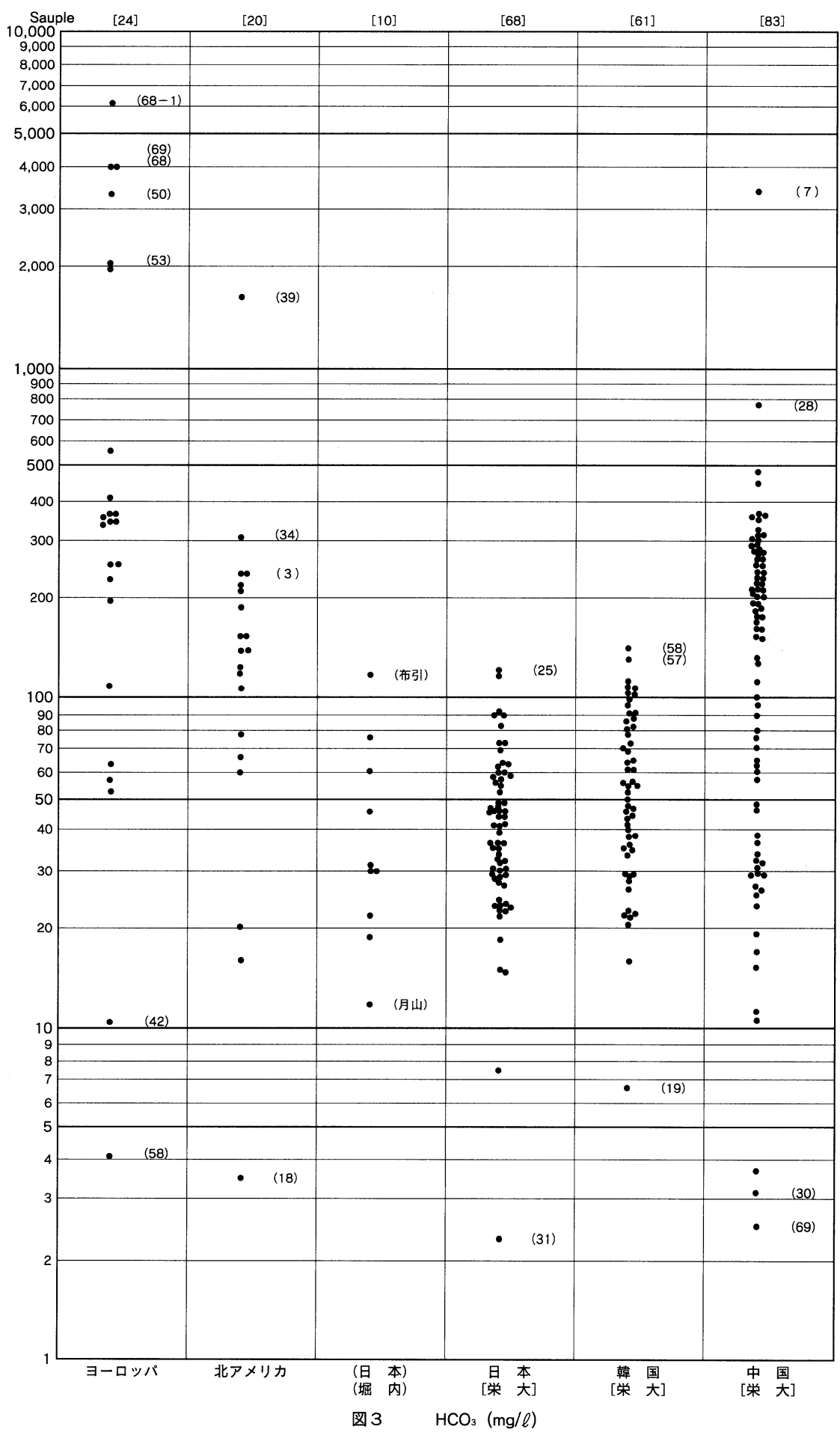


日本食生活学会誌 Vol.11 No.1（2000）

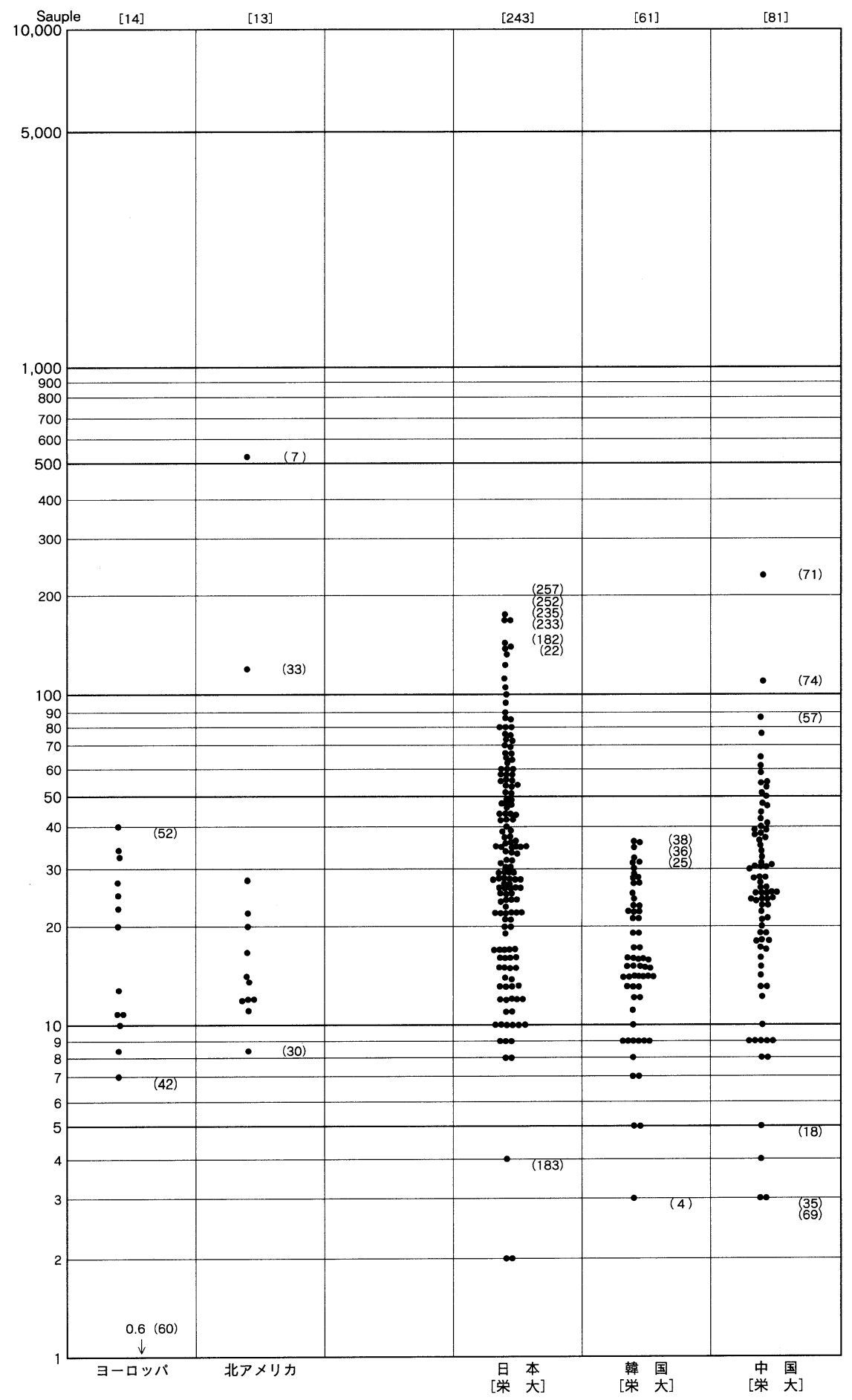

図4 $\mathrm{SiO}_{2}(\mathrm{mg} / \ell)$ 